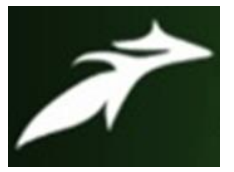

Anil Kanaujia et al, International Journal of Advances in Agricultural Science and Technology,

Vol.8 Issue.1, January-2021, pg. 45-51

ISSN: 2348-1358

Impact Factor: 6.057

NAAS Rating: 3.77

\title{
CQI - For Grading Quality of Composts
}

\author{
Anil Kanaujia ${ }^{1}$; Samanwita Banerjee ${ }^{2 *}$; Sarvesh Kumar Upadhyay ${ }^{3}$; Jainendra Gupta ${ }^{4}$ \\ ${ }^{1}$ Head R\&D, ank@arfmail.in \\ ${ }^{2}$ Microbiologist, Samanwita.banerjee@ arfmail.in \\ ${ }^{3}$ Executive, sarvesh@arfmail.in \\ ${ }^{4}$ Executive, jgupta@arfmail.in \\ DOI: 10.47856/ijaast.2021.v08i1.007
}

\begin{abstract}
Organic soil management has become the pressing need today for reversing the cycle of soil degradation and thereby putting a step forward towards soil and crop sustainability. Adverse effects of modern agricultural practices not only on the farm but also on the health of all living things and thus on the environment have been well documented all over the world.

After years of chemical fertilizer use, many Indian farmers are beginning to return to organic fertilizers. Vermicompost is a nutritive organic fertiliser rich in NKP, micronutrients like calcium (Ca), magnesium (Mg), zinc (Zn) and manganese (Mn), humic acid, acceptable C:N ratio etc. The problem of quality control is a major limitation to the efficient use of compost in modern commercial agriculture, it is very difficult to standardize and characterize the finished products. Compost Quality Index (CQI), using four specific compost quality parameters viz. total nutrient content, $\mathrm{C} / \mathrm{N}$ ratio, microbial potential and germination percent, is the best way to classify the quality of different types of compost as good, moderate, poor etc. for easy understanding at the users' level.
\end{abstract}

Keywords: Vermicompost, C/N ratio, Quality index, Pathogens, Heavy metals, Flame photometer, Atomic Absorption Spectrophotometer

\section{Introduction}

The injudicious and haphazard use of chemical in agriculture is a matter of concern in recent times. Soil deprived of one or more elements either reduces production or degrades quality of crops. It has been seen that farmers make excessive use of urea and less use of potash and micro nutrients which results in less produce due to imbalanced use of fertilizers thus affecting the soil fertility. Organic soil management has become the pressing need today for reversing the cycle of soil degradation and thereby putting a step forward towards soil and crop sustainability. Adverse effects of modern agricultural practices not only on the farm but also on the health of all living things and thus on the environment have been well documented all over the world. After years of chemical fertilizer use, many Indian farmers are beginning to return to organic fertilizers to help control soil-borne diseases improve soil properties and conserve soil moisture.

Vermicompost is a nutritive organic fertiliser rich in NKP, micronutrients like calcium $(\mathrm{Ca})$, magnesium $(\mathrm{Mg})$, zinc ( $\mathrm{Zn})$ and manganese $(\mathrm{Mn})$, humic acid, acceptable $\mathrm{C}: \mathrm{N}$ ratio and beneficial soil microbes. Additionally, vermicompost contain enzymes like amylase, lipase, cellulase and chitinase, which continue to break down organic matter in the soil (to release the nutrients and make it available to the plant roots). The soil treated with vermicompost has significantly more electrical conductivity $(\mathrm{EC})$ and near neutral $\mathrm{pH}$, scientifically proven to be excellent growth promoters and protectors for crop plants, benefits the environment by reducing the need for chemical fertilizers and decreasing the amount of waste going to landfills (Sinha, r. herat, et al, 2009) 


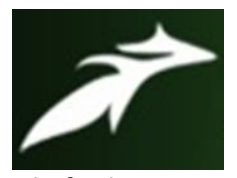

Anil Kanaujia et al, International Journal of Advances in Agricultural Science and Technology,

Vol.8 Issue.1, January-2021, pg. 45-51

ISSN: 2348-1358

Impact Factor: 6.057

NAAS Rating: 3.77

The problem of quality control is a major limitation to the efficient use of compost in modern commercial agriculture, it is very difficult to standardize and characterize the finished products. There is the danger that farmers may be buying substandard products, they also need to know the nutrient content of organic fertilizer, so as to understand how much to apply (Bera, R. et al, 2013). A major problem in compost production is the presence of toxic elements and pathogens which may be harmful to crop growth and/or human health. Two of the most plentiful sources of raw materials in industrialized societies are municipal wastes and sewage. Both these often contain unacceptably high levels of heavy metals such as arsenic, cadmium and lead and pathogens like Salmonella, E. Coli, Shigella etc. which contaminate the food chain (Bhattacharyya, P. et al., 2001).

Several parameters have been developed to determine the maturity of compost. One of the most common is determination of the $\mathrm{C} / \mathrm{N}$ ratio. During composting, the content of total carbon decreases while that of total nitrogen increases, resulting in a fall in the $\mathrm{C} / \mathrm{N}$ ratio. Other properties which give an indication of maturity include cation exchange capacity (CEC), humic substances, ash content, level of volatile gases, the colour of compost, and its smell and temperature. Hence, an effective composting method, which enables the production of good quality compost at an economical cost, can only meet the criteria for sustainable organic soil management. Compost Quality Index (CQI), using four specific compost quality parameters viz. total nutrient content, $\mathrm{C} / \mathrm{N}$ ratio, microbial potential and germination percent, is the best way to classify the quality of different types of compost as good, moderate, poor etc. for easy understanding at the users' level.

A study was planned and conducted at Ayurvet Research Foundation (ARF) R\&D Centre to evaluate the nutritional contents, pathogenic load of in house produced vermicompost and different types of organic composts available in market, calculation of CQI to do the quality grading.

\section{Material and Methods:}

Samples of ARF's in house produced vermicompost and commonly available from the markets of dist. Ghaziabad, U.P. were taken for evaluation of their quality.

\subsection{Manufacturing process for vermicompost:}

a. Added $400 \mathrm{Kg}$ of cow dung already cooled for 15 days to remove methane gas in pit and mixed $2 \mathrm{Kg}$ of neem leaves.

b. After 6 days added approx. $750 \mathrm{~g}$ of earthworms (Eisenia fetida)

c. To maintain moisture sprayed 10 litre of water in morning and $10 \mathrm{lt}$ of water in evening during peak summer / sprayed 10 litre of water every fourth day during winter continued the process for 35 days.

d. Harvested the compost on 40th day, sieved and packed (Fig: 1-3).

e. $\quad$ Yield $=200 \mathrm{Kg}$

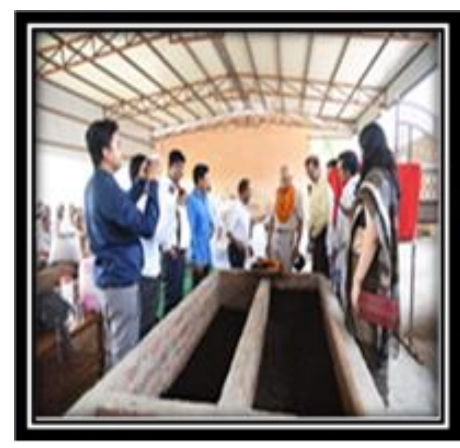

Fig.1- Vermicomposting

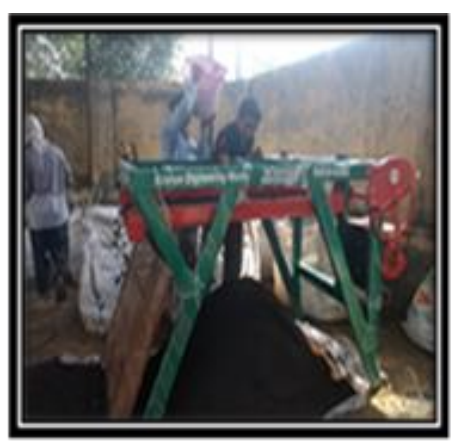

Fig.2- Sieving

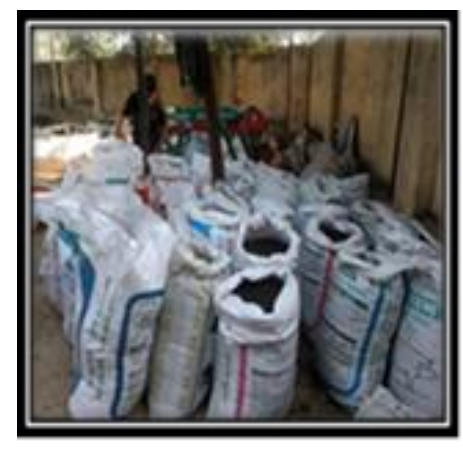

Fig.3- Packing and sealing 


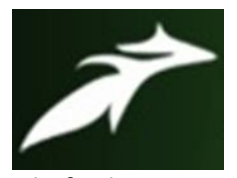

Anil Kanaujia et al, International Journal of Advances in Agricultural Science and Technology,

Vol.8 Issue.1, January-2021, pg. 45-51

ISSN: 2348-1358

Impact Factor: 6.057

NAAS Rating: 3.77

\subsection{Physicochemical and microbiological parameters analyzed:}

Colour, Moisture, Nitrogen, Phosphorus, Potassium, Sodium, Organic carbon, Humic acid, Fulvic acid, Cadmium, Mercury, Arsenic, Lead, TPC, Total Yeast and Mould Count, Total coliform count, E. coli, Salmonella. sp., S. aureus, Shigella.sp. and P. aeruginosa.

Kjeldhal methodology was used to analyze the nitrogen content, UV for Phosphorus, Flame photometer for Sodium and Potassium, Organic carbon by titration, Atomic Absorption Spectrophotometer for Arsenic, Cadmium, Mercury and Lead, Humic and Fulvic acid by gravimetry. Standard ISO methodology was adopted for the evaluation of pathogenic load (Fig.4 - 6).

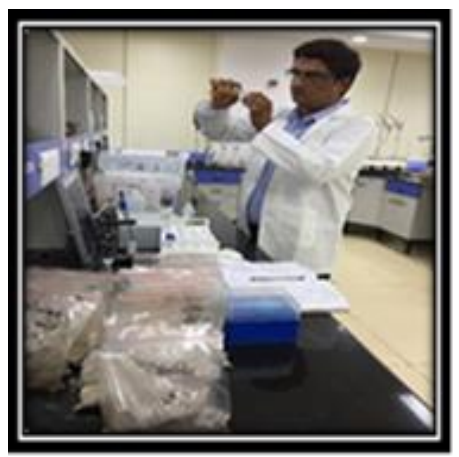

Fig.4- Chemical analysis
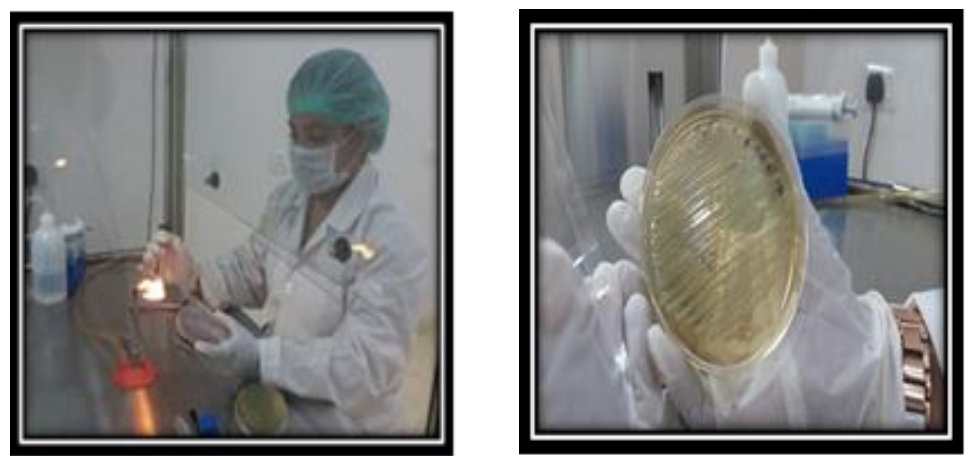

Fig 5(a) and (b) -Microbiological analysis

\subsection{Calculation of QI (Quality Index) of compost:}

Prepared nine $1 \mathrm{~m} \times 1 \mathrm{~m}$ experimental plots, watered and ploughed. Plot no. 1 was kept as control where no compost was added, $5 \mathrm{Kg}$ each of vermicompost was added in plot no. 2 to 8 and sown the known quantity of mustard seeds in each plot, measured the germination rate to calculate the GI (Germination index) as per formula, $\mathrm{GI}=\mathrm{n} / \mathrm{d}$. Where $\mathrm{n}=$ number of seedlings emerging on day' $\mathrm{d}^{\prime}$, where $\mathrm{d}=$ day after sowing.

GI = day $1, \mathrm{n} / \mathrm{d}+$ day $2, \mathrm{n} / \mathrm{d}+$ day $3, \mathrm{n} / \mathrm{d}+$ day $4, \mathrm{n} / \mathrm{d}+$ day $5, \mathrm{n} / \mathrm{d}+$ day $6, \mathrm{n} / \mathrm{d}+$ day $7 \mathrm{n} / \mathrm{d}+$ day $8 \mathrm{n} / \mathrm{d}+$ day $9 \mathrm{n} / \mathrm{d}+$ day $10 \mathrm{n} / \mathrm{d}$

$$
\text { Compost Quality Index }(\mathrm{CQI})=\frac{\mathrm{NV}_{\mathrm{NPK}} \mathrm{x} \text { MP x GI }}{\mathrm{C} / \mathrm{N} \text { ratio }}
$$

$\mathrm{NV}_{\mathrm{NPK}}=$ Total nutrient value in terms of total $\left(\mathrm{N}+\mathrm{P}_{2} \mathrm{O}_{5}+\mathrm{K}_{2} 0\right)$ percent.

$\mathrm{MP}=\log _{10}$ value of total microbial population in terms of total bacteria, total fungi and total actinomycetes. $\mathrm{GI}=$ Germination Index .

Classification of compost as per Quality Index

\begin{tabular}{|l|l|l|}
\hline \multicolumn{2}{|c|}{ Index (CQI) } & \multicolumn{1}{c|}{ Classification } \\
\hline \multicolumn{2}{|c|}{$<2.00$} & Poor \\
\hline 2.00 & -4.00 & Moderate \\
\hline 4.00 & -6.00 & Good \\
\hline 6.00 & -8.00 & Very Good \\
\hline 8.00 & -10.00 & Extremely Good \\
\hline
\end{tabular}




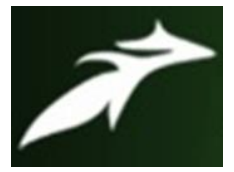

Anil Kanaujia et al, International Journal of Advances in Agricultural Science and Technology,

Vol.8 Issue.1, January-2021, pg. 45-51

ISSN: 2348-1358

Impact Factor: 6.057

NAAS Rating: 3.77

\section{Results:}

Table 1: Physicochemical analysis of in house produced vermicompost and samples available in market.

\begin{tabular}{|c|c|c|c|c|c|c|c|c|c|}
\hline \multirow[t]{2}{*}{ Parameter } & \multirow{2}{*}{$\begin{array}{c}\text { Limits } \\
\text { (The Fertilizer Control } \\
\text { Order 1985) }\end{array}$} & \multicolumn{8}{|c|}{ Samples } \\
\hline & & 1 & 2 & 3 & 4 & 5 & 6 & 7 & 8 \\
\hline pH & NA & $\begin{array}{c}6.54- \\
6.87 \\
\end{array}$ & 7.67 & 8.40 & 8.74 & 6.76 & 7.79 & 8.75 & 8.30 \\
\hline Bulk density, $\mathrm{g} / \mathrm{cm}^{3}$ & $0.7-0.9$ & 0.85 & 1.1 & 0.75 & 0.9 & 0.85 & 1.2 & 0.8 & 1.05 \\
\hline Moisture, \% & $15-25$ & 32.7 & 59.58 & 37.28 & 46.15 & 61.0 & 60.11 & 44.08 & 52.32 \\
\hline Nitrogen, \% & NLT 1.0 & 1.12 & 0.52 & 1.12 & 1.92 & 0.75 & 0.58 & 1.34 & 0.69 \\
\hline Phosphorus, \% & NLT 0.35 & 0.43 & 0.46 & 0.35 & 0.44 & 0.02 & 0.00 & 0.63 & 0.00 \\
\hline Potassium, \% & NLT 0.66 & 0.63 & 0.00 & 1.51 & 3.74 & 0.52 & 0.65 & 2.68 & 0.51 \\
\hline Organic Matter, \% & NA & 85.10 & 73.86 & 57.51 & 81.62 & 78.55 & 73.63 & 67.50 & 73.78 \\
\hline Ash, \% & NA & 14.90 & 26.14 & 42.49 & 18.62 & 21.45 & 26.37 & 32.50 & 26.22 \\
\hline $\begin{array}{l}\text { Acid Insoluble Ash, } \\
\%\end{array}$ & NA & 11.87 & 22.77 & 27.87 & 7.17 & 17.79 & 21.75 & 19.10 & 21.41 \\
\hline Organic Carbon, \% & NLT 18.0 & 18.7 & 17.31 & 20.92 & 25.49 & 17.76 & 17.03 & 21.89 & 20.40 \\
\hline C: N Ratio & NA & 16.67 & 33.28 & 18.67 & 13.27 & 23.68 & 29.36 & 16.33 & 29.56 \\
\hline $\begin{array}{l}\text { Water holding } \\
\text { capacity, \% }\end{array}$ & $\mathrm{NA}$ & 32.17 & 32.24 & 46.11 & 35.20 & 31.63 & 30.14 & 42.52 & 36.21 \\
\hline
\end{tabular}

Legends: NLT = Not Less Than; NMT = Not More Than; NA= Not Available 


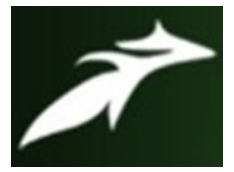

Anil Kanaujia et al, International Journal of Advances in Agricultural Science and Technology,

Vol.8 Issue.1, January-2021, pg. 45-51

ISSN: 2348-1358

Impact Factor: 6.057

NAAS Rating: 3.77

Table 2: Microbiological analysis of In-house produced vermicompost and samples available in market

\begin{tabular}{|c|c|c|c|c|c|c|c|c|c|}
\hline \multirow[t]{2}{*}{ Parameter } & \multirow{2}{*}{$\begin{array}{l}\text { Limits (The } \\
\text { Fertilizer } \\
\text { Control } \\
\text { Order 1985) }\end{array}$} & \multicolumn{8}{|c|}{ Samples } \\
\hline & & 1 & 2 & 3 & 4 & 5 & 6 & 7 & 8 \\
\hline Total Plate Count/g & $\mathbf{N A}$ & $\begin{array}{c}6.5 \times 10^{5} \\
\mathrm{CFU}\end{array}$ & $\begin{array}{l}1.3 \times 10 \\
{ }^{7} \mathrm{CFU}\end{array}$ & $\begin{array}{l}1.4 \times 10 \\
{ }^{7} \mathrm{CFU}\end{array}$ & $\begin{array}{l}5.4 \times 10 \\
{ }^{5} \mathrm{CFU}\end{array}$ & $\begin{array}{l}1.2 \times 10 \\
{ }^{7} \mathrm{CFU}\end{array}$ & $\begin{array}{l}1.5 \times 10 \\
{ }^{7} \mathrm{CFU}\end{array}$ & $\begin{array}{l}8.2 \times 10 \\
{ }^{5} \mathrm{CFU}\end{array}$ & $\begin{array}{l}9.0 \times 10 \\
{ }^{6} \mathrm{CFU}\end{array}$ \\
\hline $\begin{array}{l}\text { Total Yeast and } \\
\text { Mould Count/g }\end{array}$ & NA & $\begin{array}{c}5.1 x \\
10^{3} \\
\text { CFU }\end{array}$ & $\begin{array}{l}5.3 \times 10 \\
{ }^{4} \mathrm{CFU}\end{array}$ & $\begin{array}{l}3.0 \times 10 \\
{ }^{3} \mathrm{CFU}\end{array}$ & $\begin{array}{l}<10 \\
\mathrm{CFU}\end{array}$ & $\begin{array}{l}1.9 \times 10 \\
{ }^{3} \mathrm{CFU}\end{array}$ & $\begin{array}{l}4.5 \times 10 \\
{ }^{4} \mathrm{CFU}\end{array}$ & $\begin{array}{l}2.7 \times 10 \\
{ }^{3} \mathrm{CFU}\end{array}$ & $\begin{array}{l}5.2 \times 10 \\
{ }^{4} \mathrm{CFU}\end{array}$ \\
\hline $\begin{array}{l}\text { Total Coliform } \\
\text { Count/g }\end{array}$ & NA & $\begin{array}{c}3.2 \\
\times 10^{2} \\
\mathrm{CFU}\end{array}$ & $\begin{array}{l}1.7 \times 10 \\
{ }^{4} \mathrm{CFU}\end{array}$ & $\begin{array}{l}3.0 \times 10 \\
{ }^{2} \mathrm{CFU}\end{array}$ & $\begin{array}{l}<10 \\
\mathrm{CFU}\end{array}$ & $\begin{array}{l}7.6 \times 10 \\
{ }^{3} \mathrm{CFU}\end{array}$ & $\begin{array}{l}3.5 \times 10 \\
{ }^{3} \mathrm{CFU}\end{array}$ & $\begin{array}{l}<10 \\
\mathrm{CFU}\end{array}$ & $\begin{array}{l}6.1 \times 10 \\
{ }^{3} \mathrm{CFU}\end{array}$ \\
\hline Escherichia coli/g & Absent & Absent & Absent & Absent & Absent & Absent & Absent & Absent & Absent \\
\hline $\begin{array}{l}\text { Staphylococcus } \\
\text { aureus/g }\end{array}$ & Absent & Absent & Absent & Absent & Absent & Absent & Absent & Absent & Absent \\
\hline Salmonella. sp. /g & Absent & Absent & Absent & Absent & Absent & Absent & Absent & Absent & Absent \\
\hline Shigella sp./g & Absent & Absent & Absent & Absent & Absent & Absent & Absent & Absent & Absent \\
\hline $\begin{array}{l}\text { Pseudomonas } \\
\text { aeruginosa /g }\end{array}$ & Absent & Absent & Absent & Absent & Absent & Absent & Absent & Absent & Absent \\
\hline
\end{tabular}

Legends: NA- Not Available. 


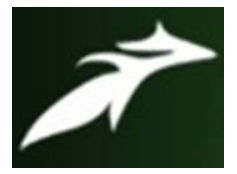

Anil Kanaujia et al, International Journal of Advances in Agricultural Science and Technology,

Vol.8 Issue.1, January-2021, pg. 45-51

ISSN: 2348-1358

Impact Factor: 6.057

NAAS Rating: 3.77

\section{Discussion:}

Moisture content in all samples was found to be in range of $32.7-61.0 \%$, well beyond the specified range $15.0 \%-25.0 \%$. N and P contents of only 4 samples $(1,3,4 \& 7)$ were found to be well above the specified range. Ash and Acid insoluble ash of all samples were found to be in range of $14.90 \%-42.49 \%$ and $7.17 \%$ $27.87 \%$, respectively. OC in all samples was found to be in range of $17.03 \%-25.49 \%$, close to or above the specified limit of $18.0 \%$, C: $\mathrm{N}$ ratio was found to be in range of $13.27 \%-33.28 \%$ against the specified limit of 20:1 (Table 1). Pathogen load in all samples were found to be within specified limit (Table 2). Experiment conducted to evaluate the QI (Quality Index) of all composts on scale of < 2- 10 (poor to extremely good) revealed quality of vermicompost samples no. 1,3,4 and 7 were found to be in scale of $4.0-6.0$ or good quality, whereas vermicompost sample 5 was found to be in scale of $2.0-4.0$ or moderate quality and sample nos. $2,6,8$ were found to fall in the scale of $<2.00$ or poor quality.

\section{Conclusion:}

The problem of quality control is a major limitation to the efficient use of compost in modern commercial agriculture, it is very difficult to standardize and characterize the finished products. Two of the most plentiful sources of raw materials in commercially produced composts are municipal wastes and sewage. Both these often contain unacceptably high levels of heavy metals such as arsenic, cadmium and lead and pathogens like Salmonella, E. Coli, Shigella etc. which contaminate the food chain. Compost maturity is also an important aspect of compost quality. Several parameters have been developed to determine the maturity of compost. Compost Quality Index (CQI), using four specific compost quality parameters viz. total nutrient content, C/N ratio, microbial potential and germination percent, is the best way to classify the quality of different types of compost as good, moderate, poor etc. for easy understanding at the users' level. Experiments conducted at Ayurvet Research Foundation (ARF) R\&D Centre to evaluate the nutritional contents, pathogenic load of in house produced vermicompost, different types of organic composts available in market helped in grading the quality of samples, this study will definitely help in creating the mass awareness among the end users and help them in purchasing good quality vermicompost from reliable source for optimal productivity.

\section{References}

[1]. Bera, R., Datta, A., Bose, S., Dolui, A.K., Chatterjee, A.K., Dey, G.C., Barik, A.K., Sarkar, R.K., Majumdar, D. and Seal, A., 2013, Comparative evaluation of compost quality, process convenience and cost under different composting methods to assess their large-scale adoptability potential as also complemented by compost quality index., International Journal of Scientific and Research Publications, 3(6), 1-11.

[2]. Pradip Bhattacharyya., Kalyan Chakrabarti, A. Chakraborty, B. Bhattacharya, 2001, Characterization of municipal solid waste compost in relation to maturity, stability and heavy metals content and pathogens. Indian Journal of Agricultural Science, 71 (12), 791-793.

[3]. Sinha, R., Herat, S., Valani, D., Chauhan, K., 2009, Earthworms Vermicompost: A Powerful Crop Nutrient over the Conventional Compost \& Protective Soil Conditioner against the Destructive Chemical Fertilizers for Food Safety and Security. American-Eurasian Journal of Agricultural \& Environmental Sciences, 5(S), $01-55$.

\section{A Brief Author Biography}

Dr. Anil Kanaujia - Skilled Scientist with 24+ years of experience in natural product chemistry and medicinal chemistry based new drug discovery research, process chemistry, research on food safety, isolation \& characterization of molecules from medicinal plants using Flash chromatography , 1H, 13C and 2D NMR spectroscopic techniques; commercialization of standardized herbal extracts, standardization of polyherbal formulations, analytical research \& method development and validation using HPLC-PDA, HPTLC, AAS, UV VIS spectrophotometer etc. techniques. Currently working with the AYURVET RESEARCH FOUNDATION, Sonepat, Haryana, as Head- R\&D, managing and providing the guidance on 


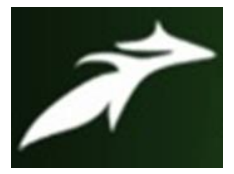

Anil Kanaujia et al, International Journal of Advances in Agricultural Science and Technology,

Vol.8 Issue.1, January-2021, pg. 45-51

ISSN: 2348-1358

Impact Factor: 6.057

NAAS Rating: 3.77

innovative research projects to the team of professionals. Credited with 14 patents (10 US, 1 Chinese, 3 Indian), published 25 research articles in peer reviewed international and national journals.

Samanwita Banerjee - Skilled and educated professional with M.Sc. microbiology from Bangalore University in the year 2010. Having more than 7 years of experience of performing various microbiological and chemical testing, Research and Development in the areas of research on food safety, analytical research, feeds analysis, Milk analysis, quantification of active ingredient in medicinal plant. Having an experience on Instrumentation such as ELIS A technique, UV spectroscopy, Flame photometer, IR moisture balance, STFR machine, etc. Published 5 research articles in peer reviewed international and national journals.

Mr. Sarvesh Kr. Upadhyay- Mr. Sarvesh Kumar Upadhyay, aged 36 years, holds a master's degree in applied Biochemistry in 2007 and started his carrier with Department of Biotechnology, Govt. of India, as Junior Research Fellow (JRF) from 2008- 2013. He carries rich experience of 12 years in Research and Development in the areas of research on food safety, analytical research, determining quality of incoming ingredients and outgoing feeds, Milk analysis, quantification of active ingredient in medicinal plant and has published 4 research papers in national \& international journals.

Mr. Jainendra Gupta- Skilled and educated professional with more than 10+ years of experience on performing various rural development activities. Having graduation in agriculture from Dindayal Upadhyay Gorakhpur University, Gorakhpur, U.P in the year 2007. Having experience in rural development activities such Vermicomposting production, organic farming, Farmers Training, Self Help Groups (SHGs), Farmer Producer Organization (FPO), Farmer Clubs formation, Biogas, Fish Farming, etc. having experience in CSR activities Sanjeevani project, human health campaigning, toilet construction, solar light installation, stadium hall construction, science lab construction, biogas and Vermicompost unit construction. Currently working as Sr. Rural project in charge with Ayurvet research foundation, leading the rural team members. 